\title{
Teaching English as Discourse in Sultan Qaboos University
}

\author{
Khalid Mohammed Al-Balushi \\ Sultan Qaboos University, Oman
}

\begin{abstract}
In this paper, I argue that English could be of more relevance to the Arabian Gulf if we conceptualized it as an educational forum for familiarizing students with socio-linguistic conventions relating to a wide variety of text types and for sharpening their critical awareness of the political implications of the uses of English. I make my case against the backdrop of a particular local context in the Arabian Gulf: the current BA programme in English at the College of Arts and Social Science, Sultan Qaboos University, the Sultanate of Oman. I maintain that the programme is predicated upon conceiving of English as a field (or rather fields) of knowledge, as academic disciplines of English literature, linguistics and translation, each with its own sets of concepts and frames of reference. As such, the programme both falls short of being fully theoretically coherent and fails to take into account the recent educational developments in Oman. Drawing upon the theoretical construct of discourse, I propose an outline of an alternative BA programme in English that revolves around the uses of English and their political implications.
\end{abstract}

\section{The Basic Education Initiative in Oman}

In 1995, the Ministry of Education in the Sultanate of Oman initiated a new educational policy, referred to as the Basic Education System, (Al-Hammami 1999: 12), whereby emphasis is given to mathematics, science and English. The inception of this system is aimed at

facing the challenge of preparing its children for life and work in the new conditions created by the modern global economy. These conditions will require a high degree of adaptability and strong backgrounds in mathematics, science, technology and languages in order to deal with rapidly changing technologies and developing international business opportunities. (Ministry of Education, 1999: 1)

The Basic Education System seeks to develop human capital, equipping students with suitable capabilities and skills to participate in the economic development of the country. It also aims to develop students' critical thinking, problem solving ability and creativeness and to provide them with conditions to investigate phenomena on their own (Ministry of Education, 2004: 16).

Indeed, these principles are in line with the avowed vision of Sultan Qaboos University (henceforth referred to as SQU). It is stated as the vision of the University that it aspires to foster critical thinking and self-dependence (College of Arts and Social Sciences, 2003: 3). As a college of SQU, the College of Arts and Social Sciences

seeks to provide Omani society with competent graduates who are critical thinkers committed to the pursuit of intellectual distinction, and are equipped to perform effectively at professional levels of social and economic importance in a changing global community. (College of Arts and Social Sciences, 2006:6)

I shall now describe the content and structure of the BA programme in English. 


\section{The Description of the BA Programme in English}

After taking a one-year foundation programme in English in the Language Centre ${ }^{1}$, and upon fulfilling an equivalent of Band 4.5 of IELTS, students join the BA programme in English in the College of Arts and Social Sciences. The following are the courses they take over six semesters.

Table 1: Courses in the SQU BA programme in English. (The number in parentheses after each course refers to the semester in which the course is taken.)

\begin{tabular}{|c|c|c|c|}
\hline LANGUAGE & LITERATURE & LINGUISTICS & TRANSLATION \\
\hline $\begin{array}{l}\text { Modern English } \\
\text { Grammar (3) } \\
\text { Effective Reading (3) } \\
\text { Effective Writing (4) } \\
\text { Speaking (5) } \\
\text { Advanced Writing (6) }\end{array}$ & $\begin{array}{l}\text { Introduction to Fiction } \\
\text { (3) } \\
\text { Introduction to Poetry } \\
\text { \& Drama (4) } \\
\text { American Survey One } \\
\text { (5) } \\
\text { British Survey One (5) } \\
\text { American Survey Two } \\
\text { (6) } \\
\text { British Survey Two (6) } \\
\text { Modern Drama (6) } \\
\text { Modern Novel (7) } \\
\text { British Survey Three (7) } \\
\text { Modern Novel (7) } \\
\text { Shakespearean Drama } \\
\text { (8) } \\
\text { Modern Poetry (8) } \\
\text { World Literature in } \\
\text { English (8) }\end{array}$ & $\begin{array}{l}\text { Introduction to the } \\
\text { Study of Language \& } \\
\text { and Phonetics (3) } \\
\text { Morphology and } \\
\text { Phonology(4) } \\
\text { Syntax and } \\
\text { Semantics(5) } \\
\text { Language and Society } \\
\text { (7) } \\
\text { Discourse Analysis and } \\
\text { Pragmatics (8) }\end{array}$ & $\begin{array}{l}\text { Introduction to } \\
\text { Translation I (3) } \\
\text { Introduction to } \\
\text { Translation II (4) } \\
\text { Translation III (6) } \\
\text { Translation Studies (7) }\end{array}$ \\
\hline 5 courses & 12 courses & 5 courses & 4 courses \\
\hline
\end{tabular}

As the table shows, there are thirteen courses in literature, five in language, five in linguistics and four in translation. In addition to the courses mentioned in the table, there are two departmental electives chosen by students and a course on modern Arabic literature (translated into English).

The following is a description of the courses in all the four areas: literature, language, linguistics and translation ${ }^{2}$.

\section{Literature}

On taking two introductory courses to literature, Introduction to Fiction and Introduction to Poetry and Drama, in semesters three and four respectively, students embark upon a chronological study of English literature starting with British Survey One and American Survey One in semester five. With an emphasis on the Elizabethan and Stuart reigns, the former focuses on selected works of British literature from the Anglo-Saxon period to the Restoration, while the latter focuses on early American literature covering the period from the beginning of the seventeenth century to the middle of the nineteenth century. In semester six, students take both British Survey Two and American Survey Two. The former covers British literature from the period between Restoration and the first generation of the Romantic Movement, 
while the latter surveys American literature from the mid-nineteenth century to 1914 . The second generation of the Romantics and the Victorian Age are taught in British Survey Three.

In their final year, students are introduced to modern literature. Modern Novel helps them understand the various thematic and stylistic developments of the modern novel, while Modern Poetry is aimed at enabling students to understand the themes and techniques of modern poetry. In addition to this, students take World Literature in English, a course that concentrates on contemporary "cosmopolitan" literature in English. It includes authors such as Samuel Beckett and V. S. Naipaul. There are also a course in modern Arabic literature translated into English and a course in Shakespearean drama.

\section{Language}

There are one grammar course, one reading course, one speaking course and two writing courses. Modern English Grammar and Effective Reading are offered in semester three. The former provides both instruction and practice in English grammar, while the latter is aimed at developing effective reading strategies with an emphasis on vocabulary development. In semester four, students take Effective Writing, which helps them write for different purposes and audiences. They write a variety of text types such as narratives, descriptions, directions, memos and formal letters. In semester five, students take Advanced Writing, which familiarizes them with the principles of research: how to define research questions and follow them through with methodologically supported arguments. In addition, they are expected to give an oral presentation based on their research experience. The last language course, taken in semester six, is Speaking. It helps students develop the skills needed to speak in a variety of public settings.

\section{Linguistics}

The first course in linguistics, Introduction to the Study of Language and Phonetics, familiarizes students with the properties of language that distinguish it from other systems of communication. It also presents a basic grounding in articulatory phonetics and the phonemic transcriptions of words. Phonology and Morphology (semester four) offers an introduction to the phonemes and the phonology of English. It includes topics such as syllable structure, word stress, rhythm and intonation as well as the processes of word formation and inflection. Syntax and Semantics (semester five) examines sense relations and semantic features. Focusing on the techniques of syntactic analysis, it helps students analyze meaning. Language and Society and Discourse Analysis and Pragmatics (semester seven and eight respectively) are geared towards sociolinguistics. They examine issues such as the communicative functions of different language forms and the relationship between language and its users.

\section{Translation}

The first course in translation, Introduction to Translation I (semester three), introduces students to English-Arabic and Arabic-English translation. Introduction to Translation II (semester four) focuses on the translation of texts with a variety of styles and registers from Arabic to English. Building upon these two courses and placing emphasis on developing students' awareness of translation problems, Translation III (semester five) focuses upon translating informative, argumentative, and instructive texts. The last course on translation, Translation Studies (semester seven), exposes students to different theories and approaches to translation with an emphasis on critical analysis and evaluation of different translated texts in both English and Arabic.

In the following section, I shall try to assess the Programme in view of the principles of the Basic Education System and the vision of SQU. 


\section{An Assessment of the BA Programme in English}

Considering the number of courses allocated to each area of study, it could be claimed that the programme is heavily weighted towards literature. Students embark upon a chronological study of literature starting with old English literature immediately after taking two introductory courses to fiction, poetry and drama.

Several reservations can be voiced against such a structure. First of all, students begin the programme with a level of English equivalent to Band 4.5 of IELTS. The scorer of Band 4 is described on the British Council website www.ielts.org as a limited user whose "basic competence is limited to familiar situations [and has] frequent problems in understanding and expression [and is] not able to use complex language". The irony is that such a limited user of English is exposed to old English literature with its archaic words and spellings as well as its remote cultural references. In the name of allegiance to the chronological study of literature, students are exposed, in semester five, to poems such as The Twa Corbies:

As I was walking all alane,

I heard twa corbies making a mane

The tane unto the t'other say

... (anon.)

or Chaucer's Canterbury Tales:

Whan that April with his showres soote

The droughte of March hath perced to the roote

And bathed every veine in swich licour

...

or Middle English lyrics like The Cuckoo Song:

Summer is ycomen in,

Loude sing cuckou!

...

or Milton's:

When I consider how my light is spent

Ere half my days in this dark world and wide,

And that one talent which is death to hide

Lodged with me useless, though my soul more bent

...

Indeed, even in Introduction to Poetry and Drama, offered in semester three, some such poems are taught. While doing my PhD studies from 2003 to 2007 at the University of Nottingham, I sat in on Introduction to Poetry ${ }^{3}$ as part of my studies (Al-Balushi, $2007 \mathrm{Ch}$. 6). Some of the poems that the teacher taught were "'Western Wind" (anon.), 'The Three Ravens", (anon.) and "Twa Corbies" (anon.). I sat in on this course for three weeks in February-March 2006.

On the basis of the notes I took while in the class (Al-Balushi, 2007: 306-8, Appendix Two), I drew the conclusion that the pedagogic approach was heavily teacher-centred. The teacher-centredness took various forms. The teacher sometimes defined words and phrases and commented upon imagery, tone and theme of the poem in question. He also provided technical information with respect to literary devices and the kinds of poems being discussed (whether a sonnet, haiku, limerick, etc). The teacher occasionally gave background information as to the biography of the poet and the era in which he/she lived. 
Regarding the students' participation in the class, I noticed the activity they were most engaged with was writing notes and reading the poems at the beginning of the class. They also occasionally asked questions regarding meanings of certain words and phrases. At other times, they attempted to answer the teacher's questions with respect to figures of speech and musical devices. Noticeably, they seldom expressed their responses or readings, or questioned the interpretations of the teacher.

My understanding is that the teacher-centredness that was the feature of the course I sat in on characterizes most of the literature (and particularly poetry) courses. This view is based on several factors. Firstly, in addition to sitting in on Introduction to Poetry, I was a BA student in the English Department from 1992 to 1996. Secondly, I have been teaching literature since 1998 and have always seen myself resorting to a teacher-centred approach, as a way to get round the archaic words, contorted syntax and the cultural and religious allusions in poems such as the ones quoted above.

Such an approach to teaching relies more on transmitting knowledge than on creating conditions and contexts whereby students are both encouraged and helped to explore literary works. This is not different from what Freire (1970) calls "banking" education, according to which students are viewed as "objects" into which teachers pour their knowledge. This approach comes in stark contravention to the principle of helping students investigate phenomena on their $\mathrm{own}^{4}$, principles enshrined in both the Basic Education System and in the visions of SQU.

In a world where the discipline of literature is confronted by the "dominant discourse of the marketplace" (Chambers \& Gregory, 2006: 1), universities around the world are expected to help students acquire skills they could apply in their respective careers. Oman is no exception to this. The graduates of the BA programme work as translators, teach in the Ministry of Education and in the armed forces and join various fields such as administration, media, banking and public relations (College of Arts and Social Sciences 2005: 22). Questions could be raised as to how the apparently inaccessible and the seemingly remote literary works could be of relevance to the graduates' careers.

I should hasten to add that my reservations are not against teaching English literature as a discipline or against the chronological study of literature. Indeed, teaching literature in such an order could be theoretically and educationally valid if taught with a fully fledged English literature BA programme and with due consideration to students' level of English. Nevertheless, the BA programme in English at SQU is more of a mixture of disparate areas than a coherent literature BA programme. As such, there does not seem to be any rationale for persisting with the chronological study of English literature other than that this is how it is taught around the world. If that is the case, then it is perhaps fair to claim that the content and structure of the programme are determined by paying allegiance more to established institutions than to the principles of the Basic Education System and the vision of SQU.

I should also mention that I am not riding the bandwagon of what Brown (2008: 1) calls "[T]he systematic marginalization, even elimination, of the humanistic disciplines in... the [Arabian] Gulf" (2008: 1). I share his view that "the humanities matter, as they always have, and particularly how they can serve to advance many of the stated national priorities in emerging nations like those of the Gulf." Nevertheless, I question whether we generate students' appreciation of and interest in English literature by introducing them to seemingly inaccessible literary works.

As for the language courses, there seems to be no clear theoretical link between them and the literature and linguistics courses. Indeed, what is lamentable, from the perspective of the Basic Education System and the vision of SQU, is that there are no language courses that pay systematic attention to independent thinking, questioning knowledge and student autonomy. In addition to this, there are no language courses that systematically attend to the uses of English in contexts like banking, media,

Al-Balushi, K.M. (2010). Teaching English as discourse in Sultan Qaboos University. Learning and Teaching in 
advertisements, newspapers. Nor are there courses that systemically focus on the political and societal implications of the uses of English in such contexts.

Like literature, linguistics is taught as a specialism, a discipline on its own: whatever connection it has with the other three areas remains implicit. With respect to translation, except for Translation Studies, all the other three courses are mainly focused on the process of translation. What seems to be lacking in these courses is the theorization of translation as a product that might influence the target culture, or as an act that is conditioned by political, cultural and ideological considerations. There is no sufficiently systematic coverage of issues such as how translations could "domesticate" foreign cultures, attempt to obliterate the original author (cf. Venuti, 1995), or why we usually translate from English to other languages and not vice versa. Although understandable from a market-oriented perspective as the four courses potentially increase the graduates' employability, the focus on the process of translation seems theoretically unsound. For it seems there lurks the assumption that translating is an ideology-free process, devoid of politics. Finally, the connection between translation and the other three areas of study is not clearly defined. Indeed, it seems that the translation courses are offered more as an immediate response to the markets' needs than a core element that coheres with literature, linguistics and language.

\section{BA in Literature, Language, Linguistics or Translation?}

It seems that "English" is conceived of in the current BA programme as academic disciplines of literature, linguistics and translation; and that the programme is founded upon developing several competencies: language competency, literary competency or translation competency. However, the four areas of language, linguistics, literature and translation are mixed somewhat haphazardly and in a fragmented manner. As such, they seem to lack in theoretical coherence. Indeed, it is difficult to label the programme as one in literature, language, linguistics or translation. It is doubtful whether we can actually call it a "programme" as such, as it appears an incoherent assemblage of different areas.

In addition, context is under-theorized across all the four areas. Communication in specific social settings does not appear prominently and systematically. The political and ideological implications associated with the uses of English receive short or no shrift at all. Insofar as the awareness of such implications is essential to autonomy and critical thinking, the programme fails to take into account the principles of the Basic Education System and the vision of SQU. In short, the BA programme does not fully and in a theoretically informed manner attend to context, both the immediate context of language use and its wider socio-political dimensions.

\section{A Proposal: Teaching English as Discourse}

I, therefore, put forward the outline of an alternative BA programme that takes as its point of departure the principles of the Basic Education System and the vision of SQU. I propose that emphasis be shifted from form to function (i.e. to the contexts in which English is used as communication) and that the relation between language and the contexts of use be critically examined.

It is ill-advised, however, to simply assemble courses that run across such diverse genres with no theoretical coherence. Fortunately, there is a theoretical construct around which we could weave a whole BA English programme that takes into account both the uses of English and the examination of power relations, i.e. discourse.

I shall now define 'discourse' and subsequently examine how it can be pedagogically drawn upon in designing a BA programme in English.

Al-Balushi, K.M. (2010). Teaching English as discourse in Sultan Qaboos University. Learning and Teaching in 


\section{Discourse}

Discourse features both in applied linguistics and in philosophy. Applied linguists view it as language in use. McCarthy (1991: 5) asserts that it "is concerned with the study of the relationship between language and the contexts in which it is used." Cook (2001:3) theorizes context as involving several elements such as paralanguage: behaviour that meaningfully contributes to the whole communication; situation: how the participants in a discourse perceive the relations between objects and people; cotext: texts that follow or precede that under discussion; inter-text: texts that are perceived by the participants to pertain to other discourses and are thought to be related to the interpretation of the discourse in question; participants, their intentions, interpretations, knowledge, beliefs and attitudes; and function.

It follows that processing a text as discourse involves examining formal properties as well as social conventions relating to the context of communication. Implicit is the presupposition that formal choices (individual lexical items, syntactic structures, patterns of sound etc.) are not arranged randomly. They rather establish a world-view as well as textual and interpersonal relations within a communicative situation (cf. Halliday 1978).

Another tradition in the literature on discourse theorizes context in such a manner that goes beyond the immediate context of communication, and is mainly drawn from the French philosopher Michel Foucault, who defines discourse as "practices that systematically form the object of which they speak" (1972: 49). Foucault (1972, 1979, 1980a and 1980b) contends that knowledge is not static or universal; it is political and conditioned by society.

The philosophical approach to discourse has had a great impact on applied linguistics. Fowler et al. (1979); Fairclough (1992a, 1992b, 1995 and 2001); Kress (1989); and Wodak (1996), amongst others, address the wider ideological ramifications of language use. Although their theoretical orientations vary, they by and large examine how power inequalities are both reflected and produced in language. From their point of view, language is not an ideology-free medium of expression. It rather "embodies specific views - or 'theories'- of reality" Fowler et al (1979: 1).

Pennycook (1994) calls for the examination of "the wider context of contexts" (ibid: 119), by which he means the background knowledge and the socio-cultural factors informing the context in question. Central to his argument is the notion that different knowledges and disciplines are linked to power and that they attempt to "normalize social institutions and practices in society," (ibid: 127). Distancing himself from what he sees as the mainstream applied linguistics, he dubs his view "critical applied linguistics," a central element of which is

a way of exploring language in social contexts that goes beyond mere correlations between language and society and instead raises more critical questions to do with access, power, disparity, desire,

difference, and resistance. (Pennycook 2001: 6)

It falls beyond the remit of this paper to critically examine the applied linguistic and the philosophical strands of discourse. My main concern here is to argue that discourse could be drawn upon pedagogically to design a BA programme in English that is sensitive to the principles of the Basic Education System and the vision of SQU and that coherently ties together all the language, literature, linguistics and translation courses.

\section{English from academic disciplines to an educational event}

As mentioned above, in the current BA programme English seems to be perceived as fields of knowledge. I suggest that the first step towards making English accountable to the principles of the Basic Education System and the vision of SQU is to change our view of English as fields of knowledge to

Al-Balushi, K.M. (2010). Teaching English as discourse in Sultan Qaboos University. Learning and Teaching in 
English as a forum for developing students' competencies relating to life in general and enhancing their creative and critical thinking. In the words of Durant (1995: 54):

If you conceive of English as a knowledge-based field, it seems perfectly reasonable to add on units or modules incrementally... If, on the other hand, you think of English as a structured educational event or practice, then curriculum revisions are quite likely to be procedural or systemic, with implications fully across the range of different topics or subject areas: an alteration in aim or pedagogic method will affect how you approach a canonical literary work as much as how you approach a work from the New Literatures, a newspaper text, a film or a soap opera.

Conceiving of English as an "educational event" allows us to discuss a broad network of social and ideological issues. Building upon the mainstream applied linguistic view of discourse, we could design courses that attend to the immediate situations in which English is used. Similarly, drawing upon Foucault's view of discourse, we could design courses that attempt to expose how the linguistic encoding reflects (and at once conditions) a particular world-view and how it establishes discourse positions. We could also engage in connecting English to wider socio-political issues such as ideology, racism, gender politics and education. In dealing with such discourses, we could question the social processes that naturalize them, and unravel the assumptions and presuppositions that underpin them. In other words, we help the students engage in a process of what Dean (1994: 4) calls "the restive problematization of the given."

Indeed, examining materials from a wide variety of cultural texts such as films, plays, soap operas and academic writings, the BA programme could even attempt to problematize cross-cultural representation: how English is used in constructing, maintaining and deconstructing identities. In other words, instead of conceiving of knowledge as a product to be transmitted to students, and instead of adopting an unquestioning attitude towards knowledge, we should, in line with the principles of the Basic Education System and the vision of SQU, conceive of knowledge as a process and adopt an approach that helps students explore and question uses of English. In short, we should help students see through language (cf. Carter and Nash, 1990).

I also propose that literature be taught as social discourse i.e. as a form of communication. Such an approach gives the opportunity to teach literature along with other discourses, so as to sensitize students to the social conventions that inform each genre. However, literary texts should not necessarily be selected for their representativeness of a particular era (sixteenth-century English literature, early seventeenth-century English literature, the Restoration and eighteenth-century English literature) or of any literary movements (Romanticism, Imagism or Realism). They should rather be chosen for their representation of certain discourses and for their potential to function as a basis for discussion and interpretation. The aim of such an approach is to sensitize students to how patterning of linguistic components in a literary work serves a communicative function, a sensitivity they could draw upon across other discourse-oriented courses in the curriculum.

This is not to downplay the importance of literature. Indeed, literature could be used to enhance students' aesthetic sensitivities and furnish them with insights into the human condition. I share Brown's (2008: 7) argument that "[S]ustained engagement with entire texts, artifacts, and ideas, not as bit players but as things unto themselves, needs to figure prominently in courses offered at both high school and university levels." However, whatever the literary works, they are to be taught in a way that is informed by the principles of education and the language level and the cultural complexity of the literary works to be taught, not by an uncritical adherence to a chronological order.

In practical terms, this involves a series of shifts of emphasis from the current BA programme. The following are possible courses. It should be noted that the courses are in no particular order and that the categorization of the courses is somewhat artificial.

Al-Balushi, K.M. (2010). Teaching English as discourse in Sultan Qaboos University. Learning and Teaching in 
An increased emphasis on contextualized English courses:

English in Business

English in Newspapers

English in Administration

English in Banks

An increased emphasis on social perspectives:

Introduction to English Discourse

English and Communication

Introduction to Sociolinguistics

Analyzing Spoken Discourse

Introduction to Cultural Studies

Language and Society

An increased emphasis on political perspectives:

Language and Culture

English and Politics

English and Identity

The Politics of English as a Global Language

World Englishes

An increased emphasis on modern uses of English:

English in Films

English in Soap Operas

English in Songs

English in Advertisement

English in Sports Commentary

An increased emphasis on critical thinking, student autonomy and developing a questioning attitude:

Critical Reading

Critical Language Analysis

Cross-cultural Representation

The Discourse of Orientalism

The Discourse of Occidentalism

A shift from literature as discipline studied chronologically to literary language as subject studied along with other discourses:

Literary Language

Creativity in Language

Stylistics

Prose Devices

Poetic Devices

Literary Language and Ideology

Al-Balushi, K.M. (2010). Teaching English as discourse in Sultan Qaboos University. Learning and Teaching in 


\section{Literature as Discourse}

The Discourse of Modernism

The Discourse of Post-modernism

An increased emphasis on translation as product:

Translation and Ideology

Translation and Culture

Translation and Semiotics

Translation and Post-colonial Theory

Translation and Politics

\section{The Theoretical and Educational Rationale of the Programme}

Drawing upon some applied linguistic and philosophical orientations of discourse, the outline of the proposed BA programme seeks to achieve discourse competence, i.e. the "mastery of how to combine grammatical forms and meanings to achieve a unified spoken or written text in different genres" (Canale 1983: 9). The genres could be as diverse as newspapers, conversation, poetry, drama, fiction and political speeches etc. Upon completion of the programme, students will be expected to have acquired skills that are applicable to a wide range of discourses such as advertisement, media studies, international relations and banking, some of the fields students go into after graduation.

Educationally, in line with the aims of the Basic Education System and with vision of SQU, students will be able to understand, analyze and criticize structural inequalities relating to, say, class, gender and the representations of others. It might also be added that by being exposed to multiple discourses students will come to recognize the multiplicity and fluidity of those discourses. They will be able to see how meaning is variable, fuzzy and conditioned by the prevalent socio-political conditions of the era in question. In short, the programme is meant to accommodate purposes that are career based as well as educational.

\section{Some Cautionary Remarks}

But some cautionary notes are warranted here. First of all, I have tied my argument specifically to SQU in the Sultanate of Oman. Though the Arabian Gulf countries share many historical, cultural and social similarities, each has its own unique personality. Therefore, the proposal has to be tailored in accordance with each country's educational agendas.

Secondly, the proposal raises far many more questions than it answers. There are a host of both political and pedagogical issues that need to be considered. As for the political, bearing in mind that any educational policy is political (Apple 2003; Bell and Stevenson 2006), the interpretation of both the political and educational authorities in the Gulf countries of concepts such as critical thinking and student autonomy may differ (perhaps even radically) from the terms laid out in this paper. If so, the politics of the paper might come across to the establishments as inappropriate, or even perhaps subversive. Indeed, within English Departments themselves, the proposal may face tough opposition from those holding different theoretical viewpoints or from powerful vested interests ${ }^{5}$. As for the pedagogical, many questions need to be addressed with respect to, amongst other things, the order and structure of the proposed courses and the educational backgrounds of those involved in teaching. Indeed, there may be the need to hire especially trained people.

Notwithstanding such reservations, the proposal is designed to serve more as a forum for discussion and raising questions as to the relation between the pedagogy of English and the wider society than a fully-

Al-Balushi, K.M. (2010). Teaching English as discourse in Sultan Qaboos University. Learning and Teaching in 
fledged BA programme. I am, in Widdowson's (1978: x) words, "not trying to present a conclusive case, but to start an enquiry."

\section{Conclusion}

In this paper, I contended that the pedagogy of English in the Arabian Gulf should be brought closer to the local contexts by upholding their educational aims. Tying my case to SQU, I argued that its current BA programme in English is a theoretically incoherent assemblage of four areas of study: English language, English literature, linguistics and translation, and that it does not fully attend to the principles of the Basic Education System and the vision of SQU. Building upon the applied linguistic and the philosophical senses of discourse, I then presented a rough sketch of an alternative BA programme, a series of literature, language, linguistics and translation courses that are connected together by the concept of discourse and that could coherently complement each other.

\section{References}

Al-Hammami, H. (1999). Education for the $21^{\text {st }}$ Century: general education reform in the Sultanate of Oman: motives, nature and strategies of implementation. Unpublished PhD Thesis. University of Birmingham.

Apple, M. (2003). The state and the politics of knowledge. London: Routledge.

Al-Balushi, K. (2007). The use of translation in teaching poetry: a theoretical exploration, with special reference to Oman. Unpublished PhD Thesis. University of Nottingham.

Bell, L. and Stevenson, H. (2006). Educational policy: process, themes and impact. London: Routledge.

Brown, C. (2008). Humanistic Inclusion: The Case for the Humanities in the Gulf. Learning and Teaching in Higher Education: Gulf Perspectives 5(2). http://www.zu.ac.ae/Ithe/Ithe05_02_04_brown.htm.

Canale, M. (1983). From communicative competence to communicative language pedagogy. In Richards, J. and Schmidt, R. (eds): Language and Communication. Harlow: Longman. pp. 2: 27.

Carter, R. and Nash, W. (1990). Seeing through language: a guide to styles of English writing. London: Blackwell.

Chambers, E. \& Gregory, M. (2006) Teaching \& Learning English Literature. London: Sage.

College of Arts and Social Sciences (2003). Daleel at takhassos wal wazeefa (A Guide to Specializations and Job Prespects). Al Khod: Sultan Qaboos University Press.

College of Arts and Social Sciences (2005). The Annual Report. Al Khod: Sultan Qaboos University Press.

College of Arts and Social Sciences (2006).College of Arts and Social Sciences. Al Khod: Sultan Qaboos University Press.

Cook, G. (2001). The Discourse of Advertising. ( $2^{\text {nd }}$ ed.) London and New York: Routledge.

Dean, M. (1994) Critical and Effective Histories: Foucault's Methods and Historical Sociology. London: Routledge.

Durant, A. (1995). Literacy and literature: principles in English studies towards 2000. In Korter, B. and Muller, K.P., Anglistische Lehre Aktuell: Probleme, Perspectiven und Praxis. Wissenschaftlicher Verlag. Trier. pp 37-59.

Fairclough, N. (1992a). Discourse and Social Change. London: Polity Press.

Al-Balushi, K.M. (2010). Teaching English as discourse in Sultan Qaboos University. Learning and Teaching in 
Fairclough, N. (1992b). Critical Language Awareness. London: Longman.

Fairclough, N. (1995). Critical Discourse Analysis. London: Longman.

Fairclough, N. (2001). Language and Power. ( $2^{\text {nd }}$ ed.) London: Longman.

Foucault, M. (1972). The Archaeology of Knowledge and the Discourse on Language. New York: Pantheon.

Foucault, M. (1979). Discipline and Punish: The Birth of the Prison. New York: Vintage.

Foucault, M. (1980a). The History of Sexuality. Volume 1: An Introduction. New York: Vintage.

Foucault, M. (1980b). Power/Knowledge: Selected Interviews and other Writings 1972-1977. New York: Pantheon.

Fowler, R. Hodge, B. Kress, G. and Trew, T. (1979). Language and Control. London: Routledge and Kegan Paul.

Freire, P. (1970). Pedagogy of the Oppressed. New York: Continuum.

Halliday, M. (1978) Language as Social Semiotic. London: Edward Arnold.

Kress, G. (1989). Linguistic Processes in Sociocultural Practice. Oxford: Oxford University Press.

McCarthy, M. (1991). Discourse Analysis for Language Teachers. Cambridge: Cambridge University Press.

Ministry of Education. (1999). English Language, Curriculum Framework. Muscat.

Ministry of Education (2004). National Report on Quality Education in Oman. Accessed 24 June 2009 at http://www.ibe.unesco.org/International/ICE47/English/Natreps/reports/oman_part_1.

Pennycook, A. (1994). Incommensurable discourses. Applied Linguistics 15, pp. 115-138.

Pennycook, A. (2001). Critical Applied Linguistics: A Critical Introduction. London: Lawrence Erlbaum.

Venuti, L. (1995) The Translator's Invisibility. London and New York: Routledge.

Widdowson, H. (1978). Teaching Language as Communication. Oxford: Oxford University Press.

Wodak, R. (1996). Disorder of Discourse. London: Routledge.

\footnotetext{
${ }^{1}$ The Language Centre teaches English to all first-year university students before they join their respective colleges.

${ }^{2}$ For a detailed description of the courses, see:

http://www.squ.edu.om/admission-registration/tabid/2696/language/en-US/Default.aspx

${ }^{3}$ Prior to 2007, there were three introductory courses to literature: Introduction to Poetry, Introduction to Drama and Introduction to Poetry. But later on the two introductory courses to drama and poetry were lumped into one: Introduction to Poetry and Drama.

${ }^{4}$ I do not intend to deliberate upon the merits and demerits of such a methodology. My main concern is to consider whether it could potentially serve the principles of the Basic Education System and the vision of the SQU.

${ }^{5}$ This impression was borne out by the powerful reactions of several teachers of literature, translation and linguistics to a talk on the topic I gave in the English Department at SQU in November, 2008.
} 